EGU2020-13762

https://doi.org/10.5194/egusphere-egu2020-13762

EGU General Assembly 2020

(c) Author(s) 2021. This work is distributed under

the Creative Commons Attribution 4.0 License.

\title{
Magmatic processes under Villarrica stratovolcano (Central Southern Volcanic Zone, Chile).
}

\author{
Paul Fugmann ${ }^{1}$, Jacqueline Vander Auwera ${ }^{1}$, Olivier Namur ${ }^{2}$, Tonin Bechon ${ }^{1}$, Olivier Bolle ${ }^{1}$, and \\ Luis Lara ${ }^{3}$ \\ ${ }^{1}$ Department of Geology, University of Liège, Liège, Belgium (p.fugmann@uliege.be) \\ ${ }^{2}$ Department of Earth and Environmental Sciences, University of Leuven, Leuven, Belgium \\ ${ }^{3}$ Servicio Nacional de Geología y Minería (SERNAGEOMIN), Santiago, Chile
}

Magmatic arcs are usually considered to be major sites of new continental crust formation. However, the detailed differentiation processes that produce the characteristic calc-alkaline trends are still controversial. More particularly, the depth of differentiation in the arc crustal column and possible changes during the lifespan of a volcano are current subject of discussion.

The Central Southern Volcanic Zone (CSVZ) in Chile is characterized by a thin crust ( $35 \mathrm{~km}$; HickeyVargas et al., 2016) and by the presence of a major dextral transpressional crustal scaled structure (Liquiñe-Ofqui Fault Zone), two features that favor a rapid ascent of magmas from the mantle wedge to the surface. Recent petrological data acquired on volcanoes of the CSZV further indicate that most of the differentiation takes place at about $0.2 \mathrm{GPa}$, a depth corresponding to a major intracrustal discontinuity. However, for Villarrica stratovolcano (VR; $39.3^{\circ} \mathrm{S}, 71.6^{\circ} \mathrm{W}$ ), estimates suggest two depths of differentiation, respectively at 0.8 and $0.2 \mathrm{GPa}$ (Morgado et al. 2015, 2017).

VR is one of the most active volcanoes in the Andean Cordilleras. Since the mid 80's, it has been constantly degasing through an open conduit filled by a summit lava lake. Several Holocene, monogenetic small eruptive centers (SECS) surround VR which forms together with Quetrupillán and Lanin stratovolcanoes a NW-SE oriented chain. It gives thus a perfect opportunity to study how the mentioned features influence the differentiation processes, their corresponding depth and the observed differentiation trends. VR is mainly composed of basaltic andesites and basaltic lavas and pyroclasts with less andesitic lavas and minor dacitic - rhyodacitic domes, while rocks from Quetrupillán and Lanin are compositionally more evolved (e.g. Hickey-Vargas et al., 1989).

Here we present mineral compositions (plagioclase, olivine, clinopyroxene) and whole-rock (lavas, pyroclasts) geochemical data for different units of VR as well as for some nearby SECS (Los Nevados, Chaillupén, San Jorge). The WR data combined with published analyses define a single differentiation trend extending from $\sim 50-71 \mathrm{wt} . \% \mathrm{SiO}_{2}$, with a compositional "Daly" gap between 58 - 62 wt.\% $\mathrm{SiO}_{2}$. Moreover, a few VR samples have high Mg\# up to $62\left(\mathrm{SiO}_{2}\right.$ 50.3-52.6, $\mathrm{MgO} 7.98$ wt.\%) and a tholeiitic affinity (e.g. AFM, $\mathrm{K}_{2} \mathrm{O} / \mathrm{Yb}$ vs. Ta/Yb). The most mafic, tholeiitic basalts found in the area where produced by the proximate San Jorge SEC (Mg\# 69, $\mathrm{SiO}_{2} 50.6, \mathrm{MgO} 9.5$ wt.\%) and interpreted by McGee et al. (2019) as reflecting a deep, melt-exhausted region of the mantle 
wedge. Major- and trace elements data together with supportive mass balance modelling and thermodynamic simulations with rhyolite-MELTS imply fractional crystallization as a major differentiation process. 